\title{
Revisiting British Investment in Latin America: The River Plate Trust Group, 1879-1963
}

\begin{abstract}
The article analyses the performance and profitability of the firms controlled by the River Plate Trust Group in Argentina and Uruguay from 1879 to 1960 to challenges the notion that British investments in the Southern Cone involved greater default or insolvency risks because of nationalism, expropriations, and over-taxation. Also known as Morris or Morrison group, River Plate Trust became the most important British business group in the region during the First Global Period, as it controlled a number of public utilities, mortgage and financial firms. Our case shows that the decline of British investment in mortgage and financial activities did not mark the end of this business cycle after WWI; rather, it signalled a change in the direction of capital flows. Capital outflows from host economies to Great Britain - via dividends - continued over the interwar period, with only a brief interruption between 1931 and 1934. The business cycle of British firms entered a new phase, characterized by stagnant British investments and increasing capital returns from Argentina and Uruguay to Great Britain.

Moreover, British public utility firms continued to invest in the River Plate until the 1940s, because profits from the region supported the distribution of high dividends to shareholders.
\end{abstract}

Keywords: British Business Groups; River Plate Trust; Financial Firms; Mortgage Companies; Public Utilities; Foreign Investment; Argentina; Uruguay

Corresponding author: e-mail: nlanciot@unr.edu.ar

Received June 5, 2020 - Accepted December 3, 2020

This is an Open Access article distributed under the terms of the Creative Commons Attribution-Non-Commercial-No Derivatives License (http://creativecommons.org/licenses/by-nc-nd/4.0/), which permits non-comercial re-use and distribution, provided the original work is properly cited, and is not altered or transformed in any way. 


\section{Introduction}

In the first global economy, British investment greatly expanded to European and American peripheries. Argentina-more than any other Latin American country-attracted significant foreign capital inflows to infrastructure, commercial and financial services associated with wool, and meat and crop exports. In 1913, long-term private foreign investment represented half the value of fixed capital stock in Argentina; Great Britain led private foreign investments with 59 per cent of overall foreign investment and 62 per cent of all foreign companies in the country (UN-CEPAL 1959).

The boom of British investment in Latin America, particularly in Argentina, from 1870 to 1914, has been well analysed. Research shows that following World War I (WWI), European capital ceased to flow into the country and American investment began. From the British perspective, this booming cycle ended when the British economy started to decline as a result of macroeconomic, technological, and institutional factors (Jones 2000; Jones and Wale 1998; Miller 1998; Hannah 2009; Coopey and Lyth 2009). According to Platt (1977), British capital withdrew from the region because of rising economic nationalism in Latin American countries that threatened British companies. ${ }^{1}$ Charles Jones (1980), in his study of the Morrison/River Plate Trust Group, argues that paradoxically, it is British investment in Argentina that may have fuelled local political leaders' nationalism and prompted the end of the former liberal, cosmopolitan consensus of oligarchs.

\footnotetext{
1 Platt's thesis was endorsed by Charles Jones, among others. See Jones, Jones, and Greenhill (1977), and Jones (1997).
} 
From the host economy's perspective, recent long-term historical studies of foreign companies have downplayed the decline of the British presence in Argentina during World War I and extended the life cycles of British companies to the post-World War II (WWII) period (Lanciotti and Lluch 2010, 2015; Lluch and Lanciotti 2012). Even in the 1920s, when American capital inflow grew at a higher rate than its British counterpart, the latter's share of total foreign direct investment (FDI) remained higher until the railway nationalization in 1947. Therefore, British firms played a dominant role in Argentina before railways and utility companies were sold to the Argentine state.

By taking a business history approach, this study reviews the periodization of foreign investment cycles in Argentina. Our main hypothesis is that the analysis of foreign investment cycles should include both British capital exports to the River Plate area and their returns via earning transfers from host economies to Great Britain. Accordingly, we analyse investment and indebtedness cycles, paying particular attention to the capital return phase, to determine the size of earning transfers from Argentina to Great Britain during the interwar period.

The River Plate Trust, also known as the Morris or Morrison Group, became the most important British business group in the region during the first global period. It controlled multiple public utility, mortgage, and financial firms in Argentina and Uruguay. ${ }^{2}$ According to Geoffrey Jones (2000), business groups can be organized according to three different forms: unitary, network with a core company, and loose network. The River Plate Trust Group adopted the network

\footnotetext{
${ }^{2}$ River Plate Trust is currently known as The Morris-Morrison Group, a name given by Charles Jones. However, we consider that the name Morris-Morrison underlines the managerial role of John Morris and the position of Charles Morrison as a major shareholder in the first phases of the life cycle of this group. Because this business group continued operating in the River Plate region for several decades after Morris and Morrison passed away, we think the name River Plate Trust is more adequate to define the lifelong interests of this business group in the region.
} 
form, consisting of a parent company, the River Plate Trust, Loan and Agency Company (RPTLA), surrounded by a cluster of free-standing companies linked by equity, debt, interlocking directorates, management and — sometimes — by agency agreements. In addition to having individual boards in London, the companies relied on local managers located at their respective offices in Buenos Aires, Rosario, and Montevideo. ${ }^{3}$

Using River \& Mercantile Trust Ltd. (RMTR) records (University College, London), we analyse the distribution of investments, capital invested, incomes, profits, and losses of the parent company, RPTLA, and its affiliates: Mortgage Company of the River Plate (MCRP), The River Plate and General Investment Trust (RP \& GIT); Consolidated Waterworks Co. of Rosario; the Rosario Drainage Co.; and The Montevideo Waterworks Company Ltd. (MWW). The first section of this article analyses the investment, profitability, and economic performance patterns of the River Plate Trust Group's mortgage and financial companies. ${ }^{4}$ The second section focuses on the evolution of public utility companies controlled by the group and the economic strategies they pursued after the 1930 crisis.

We find the decline of British investment in mortgage and financial activities did not mark the end of this business cycle; rather, it signalled a change in the direction of capital flows. After WWI, though the inflow of British capital into financial and mortgage activities had ceased,

\footnotetext{
3 "Free-standing" companies specifically are created to operate in host economies but with a (small) headquarters in their home countries. These companies were concentrated on transport infrastructure, utilities, primary sector investments, and urban development (Wilkins 1988; Casson 1994). Charles Jones (1997) instead, proposes to analyse the forms of British investment in Latin America in the first global period as mercantile investment groups (MIGs) and autonomous overseas companies (AOCs). For an analysis of business groups in Argentina, see Barbero (2015).

${ }^{4}$ For earlier studies that measure British firms' profitability until WWI, see Davis and Huttenback (1982) and Edelstein (1976). For the profitability of British firms in Latin America, see Rippy (1948, 1953, 1959). For the performance and profitability of British banks and merchant houses over the entire period, see Jones (2000).
} 
capital outflows from Latin America to Great Britain — via dividends - continued over the interwar period, with only a brief interruption between 1931 and 1934. The business cycle of British firms entered a new phase, characterized by stagnant British investments and increasing capital returns from Argentina and Uruguay to Great Britain. However, public utility firms continued to invest in the River Plate until the 1940s, because profits from the region supported the distribution of high dividends to shareholders. ${ }^{5}$

The performance of the public utility firms controlled by River Plate Trust contrasted with that of British railways and tramway companies, the profitability of which declined steadily after the crisis in 1930 as a consequence of currency devaluation and increased competition from automotive transport. Argentina's decision to abandon the gold standard and devalue its currency had a negative impact on public utility companies. However, service monopoly conditions and sustained revenue growth, driven by a rising urban population and economic development throughout the period (cf. five-year period following the crisis in 1930), offset the drop of earnings in pounds.

Our case study shows that investments in mortgage, finance, and utilities proved complementary for the business group that controlled all the companies. Companies' profitability curves peaked at different times during the investment cycle: Whereas financial and mortgage firms ranked highest in profits before WWI, urban utilities reached their highest profitability after the war.

\footnotetext{
${ }^{5}$ For British investors, the River Plate area included the Argentine provinces of Buenos Aires, Santa Fe, Entre Ríos, and Córdoba, as well as Montevideo, Uruguay's capital city.
} 
Our evidence also shows that firms controlled by the group secured sustained profitability with low risk, thereby ensuring a long life for the River Plate Trust's operations until the mid-1940s. This finding challenges two notions, namely, that (1) British investments abroad proved more profitable than home investments but involved greater default or insolvency risks (Edelstein 1976), and (2) British investment in Latin America was hazardous because of nationalism, expropriations, and over-taxation (Rippy 1959, Jones 1997). ${ }^{6}$ After 80 years of business in the region, the parent company RPTLA was reorganized to create the River and Mercantile Trust Limited, but the agency in Buenos Aires continued to manage the remaining small British firms until the mid-1970s. The group's corporate success, in terms of profitability and survival, calls for a review of classic theses on Great Britain's waning operations in this region.

\section{British Investment in The River Plate}

Financial and mortgage operations garnered a large share of British investment in Latin America during the first global economy. In the early 1900s, British investment was reoriented from the United States and Britain toward Canada and Argentina-the London market's two new favourites at the dawn of WWI. Falling demand for foreign capital in the United States, as well as Australia's financial crisis in 1893, constrained new issuances aimed at these countries,

\footnotetext{
${ }^{6}$ According to the analysis of par value as a basis for calculating "approximate rate of returns therefrom" Rippy concluded that Latin America was a risky region for British investment (Rippy 1959). Rippy's calculations are based on data published by The Stock Exchange Year Book, The Stock Exchange Official Intelligence, and The South American Journal, which 'does not describe fully and clearly the basis of its estimates' (Rippy 1948, 63). Moreover, his sample excluded mortgage and loan companies, core British businesses that we analyse in this article (Rippy 1953, 113). Finally, his remarks refer to Latin American as a whole, so they do not explain the differences between countries or regions. Following Rippy's and Platt's thesis, Charles Jones (1997) argues that 'adverse political circumstances coupled with sectoral distributions' explained the low survival rate of AngloLatin American MIGs and AOCs.
} 
at the same time that government securities and corporate shares in Argentine railway companies gained increasing popularity in the London Stock Exchange (Platt 1985).

In 1913, new British investments overseas had begun to recede, except in Canada and Argentina, which ranked third and fourth among countries receiving FDI. The United States and Russia still topped the list of countries with the largest FDI stock, but investment flows shifted more toward Canada and Argentina. The advent of WWI prompted capital repatriation, and British government securities became the predominant investment instrument in British firms' portfolios in the River Plate, thus starting the downward trend of British investment in Argentina. However, in 1938, Argentina was still the fourth largest FDI recipient (Wilkins 2004).

The size of British direct and portfolio investments in Latin America has been debated extensively in British studies. Using records of boards of companies listed at London's Stock Exchange, Irving Stone $(1968,1977)$ noted that by 1913, British investments in Latin America amounted to $£ 1,177,462,000$, with a 46 per cent share in direct investments and 54 per cent share in portfolio investments. A little over half the stock consisted of railway company shares; the remainder was divided into utility, financial, mining, industrial, and shipping companies. Argentina topped the list of Latin American countries receiving British investment, garnering $£ 479,800,000$, with $£ 184,593,000$ in government securities and $£ 219,235,000$ in railway stocks (slightly more than half of Great Britain's total investment in Latin American railways). In Argentina, British direct investment exceeded portfolio investments, accounting for 54 per cent of Great Britain's total investments in 1913 (Stone 1977). In Uruguay, British investments (about $£ 58,400,000$ ) went to banking, railways and water services from 1890 (Barrán and Nahum 1968). 
According to Dunning (1970), 40 per cent of British portfolio investment was in railway stocks and 30 per cent was in national and local government securities. Ratios of direct-to-portfolio investment were revised in the 1980s, when FDI was redefined as an investment involving corporate management control. Previous calculations had classified investments that were channelled via free-standing companies as portfolio investments, even though they actually represented direct investments (Corley 1994; Wilkins 1988). Platt (1985) also downplayed overestimated investment portfolio rates, claiming that, by 1914, half the railway shares in the United States and India already had been sold to local investors. Goetzmann and Ukhov (2005) note that British capital invested in Argentina in securities and shares amounted to $£ 319,565,000$. Even considering these differences in calculations, by 1913, portfolio investments accounted at least for 40 per cent of overall British investments in Argentina.

British companies' board members repeatedly emphasised Argentina's attractiveness to foreign investors during shareholder meetings, describing the country as a growing economy based on rich, fertile grasslands with a rising demand for credit that could not be met by local capitals. Argentina's allure also lay in its ability to diversify its exports in response to European demand, its political stability, and, especially, its financial stability, following the reintroduction of the peso's convertibility to gold in 1899 (Lewis 1987). Argentina exported a broader range of commodities than other Latin American economies, creating profitable investment opportunities for services and activities directly or indirectly associated with export-related processes (transportation, communications, marketing, finances).

European investors also favoured Argentina and Uruguay for political reasons. Starting in the 1880 s, both became politically stable countries, with governments that openly promoted the arrival of foreign capital via indebtedness and direct investment. These conditions marked a 
contrast with other Latin American countries during the first global economy. Chile and Perutraditional destinations for British investments-were at war from 1879 to 1883, and Mexico was renegotiating its sovereign debt in the 1880s. Shortly thereafter, conflicts between the government and peasant farmers, followed by workers' mobilization and repression, led to the Mexican Revolution in 1910, turning Mexico into an unviable destination for investors (Marichal 1984; Lanciotti and Lluch 2010).

It should be noted that neither Argentina nor Uruguay passed any laws related to foreign investment until the end of WWII. The restriction on dividend remittances for a short period of time after the crisis in 1930 was a temporary measure to lower the payment balance deficit rather than a policy meant to curtail foreign investment. Thus, as soon as the economies were back on track, this restriction was lifted. Controls on profit remittances imposed by the Argentine President Perón's Administration in 1947 were also intended to limit the reduction of exchange reserves. Although the Peronist government (1946-1955) proclaimed it would promote economic nationalism, foreign investors in Argentina did not suffer the discrimination that confronted investors in other developing countries (Kelly 1952; Lanciotti and Lluch 2015; Miller 2013). ${ }^{7}$

Consequently, European capital flowed into the River Plate under the umbrella of financial companies listed at the London Stock Exchange from 1899 to 1929. At the time, the most important British trust in the region was the RPTLA. The investment strategies developed by the RPTLA resulted in the creation of a business group, River Plate Trust, a conglomerate of

\footnotetext{
${ }^{7}$ For example, exchange controls were in force only for a brief period and did not end in regulations as in India (Kapoor and Saxena 1979).
} 
free-standing companies controlled by a trading and financial parent company by means of contracts and interlocking practices.

The investment strategies and the organizational structure of River Plate Trust were similar to those employed by British groups operating in other Asian and Latin American countries. British groups doing business in Argentina, Chile, Peru, and Brazil invested in financial, railway, and utility operations, complementing their investments with the exploitation of region-specific natural resources. Advantages drawn from the ownership of intangible assets proved a strong incentive to internalize activities in specific regions, and the groups' hierarchical yet open structures enabled British capital to reach recently developed areas (Jones and Wale 1998; Miller 1998; Greenhill 1995)

Organization types were similar across all regions; their key advantage was access to local knowledge drawn from long track records in business. Differences among regions hinged on regional advantages and resources, as well as the possibility—or lack thereof—of initiating vertical integration processes based on the development of original operations or resource exploitation.

In this regard, Casson (1994) has argued that the key to analysing free-standing companies lies in the different nature of the competitive advantages in property-related industries. The concentration of free-standing companies in investments associated with ownership of specific assets abroad - for example, transport infrastructure, utilities, mining, plantations, or oil reservoirs - may be attributed the need for these industries to assess local factors during deployment stages according to qualified business judgment. Specific knowledge of locations 
and relationships with local officials became a competitive advantage that British free-standing companies exploited.

\section{River Plate Trust's Financial and Mortgage Companies}

River Plate Trust emerged from the reorganization of the failed Mercantile Bank of the River Plate venture. ${ }^{8}$ The RPTLA was created in 1881 to purchase the assets and take on the liabilities of the Mercantile Bank of the River Plate, lend money via mortgage loans in Argentina and Uruguay, and provide financial management services to companies and individuals in the River Plate area. The managing board included highly prominent members who contributed greatly to the firm's expansion. The agency brought together major shareholders of railway companies, Members of Parliament, former consuls and London stockbrokers, British investors and businesspeople living in Argentina and Uruguay, and liquidators and shareholders of the failed Mercantile Bank. The chair was John Morris, senior partner in Ashurst, Morris, Crisp and Co., which acted as RPTLA's lawyers. Morris had vast experience in the financial management of British companies and specialized in both turnaround schemes for companies in distress and securities management of British railway companies located in the United States and Canada during the mid-19th century. ${ }^{9}$

Presided over by Morris, the managing board of River Plate Trust was reorganized in 1883, and the former shareholders of the Mercantile Bank were replaced by professionals and businesspeople with broad business experience in the River Plate. Thus, in 1883, the board was

\footnotetext{
${ }^{8}$ River and Mercantile Trust Records (RMTR). The River Plate Trust, Loan \& Agency, Memorandum of Association, July 30, 1881. On the failure of The Mercantile Bank of River Plate, see Jones (1980, 2018).

${ }^{9}$ On the role of John Morris in River Plate Trust, see Slinn (1997) and Lanciotti (2011). For biographical data on Morris, see Jones (2004).
} 
integrated by William Wilson, shareholder of MWW; Edward Ashworth, a major shareholder of the Mercantile Bank (along with Charles Morrison, also director of the Buenos Aires Great Southern Railway); E.M. Underdown, a lawyer with great knowledge of English and Spanish legislation who managed several companies in Spain; and John Taylor, ex-director of the Mercantile Bank (Directory of Directors, 1880). Soon after, Charles Gunther, director of two meat companies in Argentina, and A. Fitz Hugh were appointed as members of the board. To represent the interests of past shareholders of the Mercantile Bank, the ex-secretary John Duncan and Frederick Isaac also became directors.

By 1885, the new organizational structure included three levels, specializing in the legal, managerial, and financial activities of the firm, including specific tasks such as attraction of new capital, promotion of business, and the construction of a reputation in the city of London. At the top was the managing board presided over by Morris. A second circle included the liquidators of the former Mercantile Bank, who became majority shareholders of RPTLA: Sidney Buxton, C. Wood, Alexander Henderson and Leon Isaac. A third circle was led by the trustees John Fair and Frank Parish (chair of the Buenos Aires Great Southern Railway and director of the two most important railways in Argentina, The Central Argentine Railway and The Railway of Buenos Aires and Rosario); their trajectory in Anglo-Argentinean business would sustain the reliability of RPTLA as an agent of British companies in the River Plate. ${ }^{10}$

Under the leadership of a managerial board with extensive connections in London's financial scene and investments in the River Plate, RPTLA created new financial and mortgage

\footnotetext{
${ }^{10}$ RMTR. The River Plate Trust, Loan \& Agency, 'Report of the Fourth Ordinary General Meeting, 1885.'
} 
companies. ${ }^{11}$ Morris's plan to attract fresh capital from European markets proved successful and led to the creation of two new firms that took advantage of River Plate Trust's ownership advantages in mortgage and financial businesses in Argentina and Uruguay. The call raised more capital than the company could take in such a short time, and as a result, in 1888 , the Mortgage Company of the River Plate (MCRP) and the River Plate \& General Investment Trust (RP \& GIT) were created.

The MCRP was created to tap into the growing mortgage business developed by RPTLA in Argentina and Uruguay. It could lend and receive cash on deposit, develop real estate, buy—as a principal or agent — part of all of other companies' businesses, and sell other companies' shares and bonds; eventually, it became a mortgage and financial firm like its parent company. ${ }^{12}$ Thus RPTLA acted as an MCRP agent. John Morris, Edward Ashworth, J. H. Duncan, A. Fitz Hugh, Charles J. Gunther, and William Wilson served on both boards. ${ }^{13}$

The business life cycle of MCRP lasted over half a century, until it was reorganized as The Moorside Trust Ltd. in $1946 .{ }^{14}$ The firm was created in the midst of the real estate boom to use the capital surplus earned in London with highly profitable investments (MCRP, Annual Report, 1888, 1889). Property prices rose quickly until 1889, when they began to decline. The 1890 financial crisis affected mortgage businesses only temporarily. By 1891, property values

\footnotetext{
${ }^{11}$ For an analysis of London's financial community, see Cassis (1985).

${ }^{12}$ RMTR. Agreement between the Mortgage Company of the River Plate and the River Plate Trust, Loan and Agency; Mortgage Company of the River Plate, Memorandum and Articles.

${ }^{13}$ RMCR, "Agreement between the Mortgage"; Mortgage Company of the River Plate, Memorandum and Articles.

${ }^{14}$ RMTR. The Moorside Trust, "Memorandum of Association”. For portfolio composition in the 1950s, see The Moorside Trust, Annual Report 1961.
} 
had fallen by 40 per cent and then continued to fall. In 1892, profits fell by half compared with figures in 1890, and mortgage payments went into arrears. The financial crisis hampered the firm's business, forcing it to stop all lending operations for the next few years. However, MCRP and RPTLA consolidated their market position, displacing many local players that lost their properties and went out of business.

In the 1890s, the directors of both companies (Thomas Farrell, William Wilson, and John Morris) travelled several times to Argentina to assess the situation and help companies navigate the crisis (MCRP, Proceedings, January, 1892). They were confident about the future and highlighted the Argentine economy's flexibility and resilience. In 1897, mortgage loans resumed, and the companies began to liquidate foreclosed properties. One year later, profits exceeded the 1890 results, fuelling a boom that would extend until WWI. With favourable expectations, MCRP underwent a capital increase in 1898.

Both companies greatly increased their mortgage loans, which became their core business from 1900 to 1915 (Table 1). Great Britain's involvement in WWI and the dropping demand for mortgages in the River Plate region brought about a change in RPTLA's and MCRP's investment portfolios. At first, the acquisition of British government securities was intended to contribute to financing war expenses; however, in the absence of better investment opportunities, this strategy was consolidated in the 1920s. In 1918 and 1919, the mortgage business remained nearly stationary, and the companies acquired low-priced securities. This shift caused dissent among shareholders, who, failing to understand the increase in the share of investments in British government securities, typically asked: "whereas you get only between 3 per cent, and 4 per cent, over here, after Income tax is deducted, in the Argentine you get nearly double that?" The managing board confirmed that it was more profitable to invest money 
in Argentina, but there was no demand for short-term loans because competition with Belgian and French mortgage companies had increased, and the company chose to prioritize safe investment over issuing mortgages in a saturated market (RPTLA, Proceedings, March 1918, $12-15)$.

Table 1. River Plate Trust Companies' Asset Breakdown, The Mortgage Company of River Plate and The River Plate Trust, Loan \& Agency, 1883-1957

\begin{tabular}{|c|c|c|c|c|}
\hline \multirow[b]{2}{*}{ Year } & \multicolumn{2}{|c|}{ Assets MCRP (£) } & \multicolumn{2}{|c|}{ Assets RPTLA (£) } \\
\hline & $\begin{array}{l}\text { Gold Loans on } \\
\text { first mortgages of } \\
\text { free hold } \\
\text { properties }\end{array}$ & $\begin{array}{c}\text { General } \\
\text { Investments }\end{array}$ & $\begin{array}{l}\text { Gold Loans on first } \\
\text { mortgages of free hold } \\
\text { properties }\end{array}$ & $\begin{array}{c}\text { General } \\
\text { Investments }\end{array}$ \\
\hline 1883 & & & 137,788 & \\
\hline 1886 & & & 385,508 & 91,264 \\
\hline 1888 & 200,897 & & 952,656 & 357,743 \\
\hline 1890 & 804,370 & 28,745 & $1,208,378$ & 462,065 \\
\hline 1892 & 665,599 & 48,143 & $1,150,184$ & 407,116 \\
\hline 1897 & 864,425 & 64,436 & $1,349,449$ & 281,874 \\
\hline 1900 & $1,004,148$ & 102,153 & $1,353,829$ & 307,145 \\
\hline 1904 & $1,000,802$ & 132,484 & $1,443,548$ & 350,158 \\
\hline 1908 & $1,397,717$ & 132,624 & $2,273,272$ & 256,893 \\
\hline 1912 & $1,487,587$ & 195,481 & $4,047,024$ & 474,573 \\
\hline 1916 & $1,273,823$ & 470,105 & $3,948,881$ & 456,195 \\
\hline 1918 & 850,122 & 763,812 & $2,565,697$ & $2,226,743$ \\
\hline 1920 & 871,672 & 860,634 & $2,493,287$ & $2,618,406$ \\
\hline 1924 & 752,670 & $1,027,096$ & $2,205,709$ & $3,038,856$ \\
\hline 1929 & 694,327 & $1,160,303$ & $2,030,380$ & $3,657,172$ \\
\hline 1939 & 343,748 & $1,415,351$ & 927,965 & $4,521,065$ \\
\hline 1942 & 291,526 & $1,441,689$ & 796,629 & $4,692,219$ \\
\hline 1946 & 292,485 & $1,496,901$ & $1,071,703$ & $4,672,843$ \\
\hline 1949 & 146,159 & $1,469,601$ & 601,443 & $4,410,546$ \\
\hline 1954 & & & 433,816 & $5,008,844$ \\
\hline 1957 & & & 373,104 & $5,059,254$ \\
\hline
\end{tabular}

Source: The Mortgage Co. of River Plate, Annual Reports, 1888-1949. The River Plate Trust, Loan \& Agency, Annual Reports, 1882-1957. 
Both managers and shareholders proved right. The performance of mortgage investments in Argentina, even in the unfavourable circumstances of WWI, produced more than a 10 per cent return on capital, and companies never stopped distributing dividends on ordinary stock. Companies consistently paid high dividends on their ordinary shares (cf. in the 1930s) and increased their net profits and profitability during the first global period (Figures 1,3). Return on equity (ROE) curves also maintained high rates between 1898 and 1929 (Figure 2). ${ }^{15}$

Mortgage and financial businesses continued to enjoy high profitability rates after WWI; nevertheless, RPTLA and MCRP refocused their investments on financial assets in other regions, as shown by the increased share of "General Investments" in both companies" assets starting in 1918 (Table 1). From 1933 on, the profitability of mortgage loans began to drop below 10 per cent (Figure 2). James Anderson, chairman of RPTLA, explained the situation as follows: 'Intensive competition had sprung up, which led to reduced rates of interest, but what made us hesitate to push again our business in Argentina was a change in the currency laws which affected gold contracts and deprived us of the feeling of security that we formerly had that we could depend on having our money back in gold or its equivalent" (The River Plate Trust, Loan \& Agency, Proceedings, March 1934, 6-7).

Mortgage lending continued to decrease during the 1930s until the end of the decade, when it accounted for only 18 per cent of total assets. The investment cycle in the mortgage market had come to an end, and there were no positive expectations about the future. By the end of the cycle, investments were reoriented toward the home country. In 1948, 77 per cent of MCRP's

\footnotetext{
15 These firms' profitability remained among the top-ranking until the 1930s. For a comparison with large European firm's financial profitability, see Cassis (1997).
} 
investments were in Great Britain, and only 7.7 per cent remained in the region; 74 per cent of RPTLA's investments went to Great Britain, and 12 per cent remained in Argentina and Uruguay.

In addition to the MCRP, the RP \& GIT was established in 1888 to channel investments in securities, debentures, and government bonds $;{ }^{16}$ the trust featured shareholders of the four major British railways operating in the region. In addition to acquiring stock in other group companies, the RP \& GIT acquired debentures and shares in railway companies in Latin America, Spain, and the United States, as well as gas, water supply, sanitation, and telephone companies in Latin America and securities and government bonds. Despite its apparent diversification however, 86 per cent of its total investment portfolio was located in the River Plate and, even more remarkably, almost 60 per cent of the funds it invested in Argentina and Uruguay went to loans granted to businesspeople and landowners in Argentina's Pampas area (RMTR Agreement between The River Plate; The River Plate and General Investment Trust, Proceedings, 1891, p. 1-2).

The 1890 crisis did not affect the RP \& GIT; on the contrary, the firm ventured into new business opportunities, such as the purchase of low-priced securities (The River Plate \& General Investment Trust; Proceedings, February, 1892). As Morris had advised, investments grew steadily in the 1890s, and the company seized opportunities to purchase securities at depreciated values (Table 2).

\footnotetext{
${ }^{16}$ Two of its five trustees, John Morris and James Anderson, were RPTLA directors. The other members included Edward Thornton, former British ambassador in Buenos Aires and Asunción (Paraguay), H. Doughty Browne, shareholder and head of the Buenos Aires Northern Railway, and Robert Ryrie, a businessman based in London.
} 
TABLE 2. The River Plate \& General Investment Trust -Capital, Debentures, Reserves and Assets, 1888-1961

\begin{tabular}{|c|c|c|c|c|c|}
\hline \multirow{2}{*}{ Year } & \multicolumn{2}{|c|}{ Capital in $£ s$} & \multirow{2}{*}{ 4\% Debenture stock } & \multirow{2}{*}{ Reserve Fund } & \multirow{2}{*}{$\begin{array}{l}\text { Assets in £s } \\
\text { Investments }\end{array}$} \\
\hline & Preferred stock & Deferred Stock & & & \\
\hline 1888 & & & & & 208,059 \\
\hline 1890 & 250,000 & 250,000 & & 11,633 & 514,681 \\
\hline 1894 & 250,000 & 250,000 & & 12,830 & 524,364 \\
\hline 1898 & 250,000 & 250,000 & & 20,920 & 536,865 \\
\hline 1902 & 250,000 & 250,000 & & 14,000 & 552,781 \\
\hline 1904 & 250,000 & 250,000 & & 32,500 & 541,365 \\
\hline 1910 & 250,000 & 250,000 & 250,000 & 106,000 & 910,389 \\
\hline 1914 & 250,000 & 250,000 & 250,000 & 150,000 & 966,449 \\
\hline 1918 & 250,000 & 250,000 & 250,000 & 172,000 & 965,303 \\
\hline 1920 & 275,000 & 275,000 & 250,000 & 130,000 & 986,095 \\
\hline 1922 & 275,000 & 275,000 & 250,000 & 38,390 & $1,065,226$ \\
\hline 1928 & 275,000 & 275,000 & 250,000 & 89,000 & $1,256,767$ \\
\hline 1930 & 275,000 & 275,000 & 250,000 & 100,000 & $1,363,588$ \\
\hline 1932 & 275,000 & 275,000 & 250,000 & 110,000 & $1,312,526$ \\
\hline 1934 & 275,000 & 275,000 & 250,000 & 112,500 & $1,344,882$ \\
\hline 1938 & 275,000 & 275,000 & 250,000 & 122,500 & $1,447,084$ \\
\hline 1942 & 275,000 & 275,000 & 250,000 & 139,000 & $1,344,984$ \\
\hline 1945 & 275,000 & 275,000 & 250,000 & 153,000 & $1,218,608$ \\
\hline 1947 & 275,000 & 275,000 & 250,000 & 165,000 & $1,221,001$ \\
\hline 1950 & 275,000 & 275,000 & 250,000 & 192,500 & $1,260,782$ \\
\hline 1955 & 275,000 & 550,000 & 250,000 & 200,000 & $1,318,905$ \\
\hline 1958 & 275,000 & 605,000 & 450,000 & 254,000 & $1,599,180$ \\
\hline 1961 & 275,000 & 605,000 & 450,000 & 375,564 & $1,721,639$ \\
\hline
\end{tabular}

Source: The River Plate \& General Investment Trust, Annual Reports, 1888-1961.

Promoted as a safe business, RP \& GIT offered capital that was composed equally of deferred and preferred shares. The main appeal of deferred shares is that they tend to provide higher profits while maintaining a stable market value, such that they have less potential for capital gains but carry no risks resulting from sharp drops in the value of securities and ordinary stocks.

Preferred shares also offer greater safety to shareholders in terms of dividends, and they take precedence in dividend distributions. 
From 1896 on, RP \& GIT began to buy shares and debentures of electricity holdings in Argentina. Purchases increased notably beginning in 1900, and in 1907, debentures were issued to raise additional capital. Net income also rose rapidly and reached top value in 1913 (RMTR. The River Plate \& General Investment Trust, Minutes Book). The outbreak of WWI temporarily disrupted the firm's business. After the war, an upward trend strengthened. In 1918, trustees recommended capitalizing a portion of gains accumulated in reserves. ${ }^{17}$ In the 1920 s, investments increased as money repaid from mortgage loans was used to buy British Government securities. The boom cycle for the River Plate \& General Investment Trust began then and lasted until 1930 (Table 2).

After a slowdown as a result of the 1930 crisis and WWII, a second thriving period started in the 1950s, and the company earned returns even higher than those of the 1920s. However, part of the group's investment portfolio had been moved from South America to Great Britain (The River Plate \& General Investment Trust, Annual Report, 1950). A report in 1945 mentioned that it was still a difficult time to invest in Argentina; returns on capital and interest rates had fallen, and, despite increasing dividends, the company claimed: "We have had repayments and conversions to lower rates of interest in the case of first class debenture stocks, which had previously shown us a good return of the money invested" (The River Plate \& General Investment Trust, Minutes of ordinary general meeting, February $\left.24^{\text {th }}, 1947\right)$.

This pessimistic scenario was compounded by a negative expectation of a drop in revenues as the result of nationalizations, the effects of coal shortages, and "fewer opportunities of remunerative employment of surplus funds [that] cannot but have serious repercussions on

\footnotetext{
${ }^{17}$ Following the advice, the company created an additional Capital Reserve Fund of $£ 106610$ in 1922.
} 
investment trust companies such as ours" (The River Plate \& General Investment Trust, Minutes of ordinary general meeting, February $\left.24^{\text {th }}, 1947\right)$.

The nationalization of railway, gas, water supply, and sanitation companies further reduced the trust company's interests in Argentina (Lanciotti 2015). By 1947, investments in South America accounted for only 17 per cent of total investments (The River Plate \& General Investment Trust co, Annual Report, 1950). The sales of British railways, Rosario's waterworks, and drainage companies to the Argentine state, as well as the sale of MWW to the Uruguayan state, reduced RP \& GIT's holdings in South America, marking the absolute decline of British businesses in the River Plate region. By 1958, the trust no longer had any investments in South America. However, it continued operating as the agent of other British firms in the region until the 1970s. When RPTLA was reorganized as the River \& Mercantile Trust Ltd., both companies ended their relationship and started operating as independent trusts (RMTR. The River Plate Trust, Loan \& Agency, Legal Documents. Reorganization, 1958).

Our analysis of dividends on deferred shares distributed by RP \& GIT reveals they were always higher than those paid by other trust companies but lower than dividends paid by MCRP and RPTLA until the 1920s (Figure 1). The dividends distributed by the three companies show dispersion during the business cycle in Argentina and remarkable convergence starting in the 1950s. Both RPTLA and MCRP distributed very high dividends (always above 10 per cent during the entire cycle), and RP \& GIT began to pay dividends of 10 per cent or more during the return phase of the business cycle. Our analysis also indicates that holders of MCRP and RPTLA ordinary stock had already recovered their investments by 1902 . By the second postWar period, RPTLA shareholders received a nine-fold return on their initial investment, and MCRP shareholders' returns amounted to six times their original investment. 
FigurE 1: Dividends Paid by The River Plate Trust, Loan \& Agency, Mortgage Company of the River Plate and The River Plate \& General Investment Trust, 1882-1960

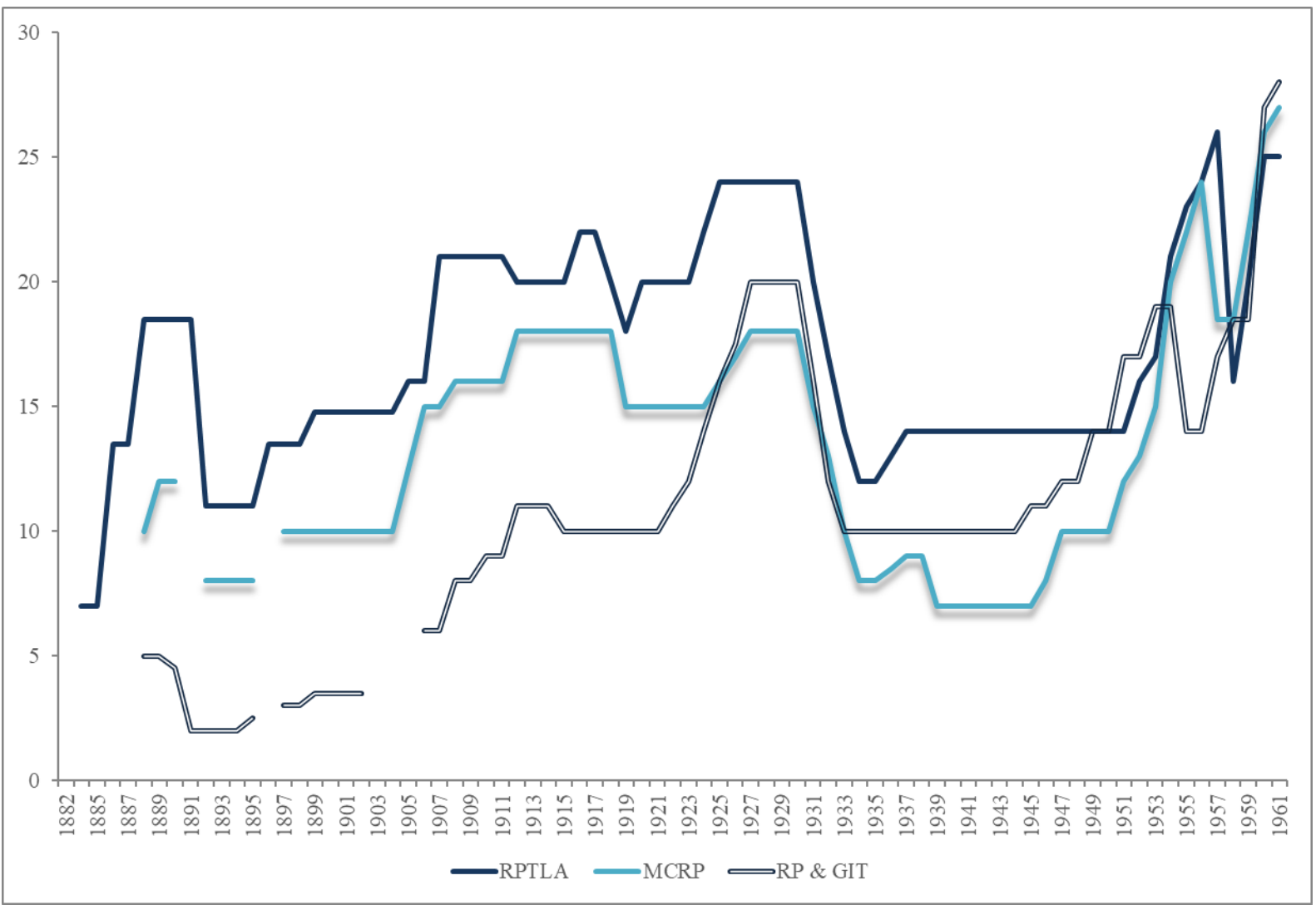

Source: The River Plate Trust, Loan \& Agency, Annual Reports, 1882-1957; Mortgage Co. of River Plate, Annual Reports, 1888-1949; The River Plate \& General Investment Trust, Annual Reports, 18881961.

The ROE also shows high profitability ratios, with peaks during the speculative periods (1880s and 1900s) (Figure 2). It did not start to drop until 1930, and this decrease mainly was a result of exchange rate losses and decreased mortgage operations. A comparative analysis of net profits reveals the parent company's earnings exceeded the net profits of other group's companies by several times (Figure 3). 
FIGURE 2. Return on Equity (ROE)** of The River Plate Trust, Loan \& Agency, Mortgage Company of the River Plate and The River Plate \& General Investment Trust, 1882-1961

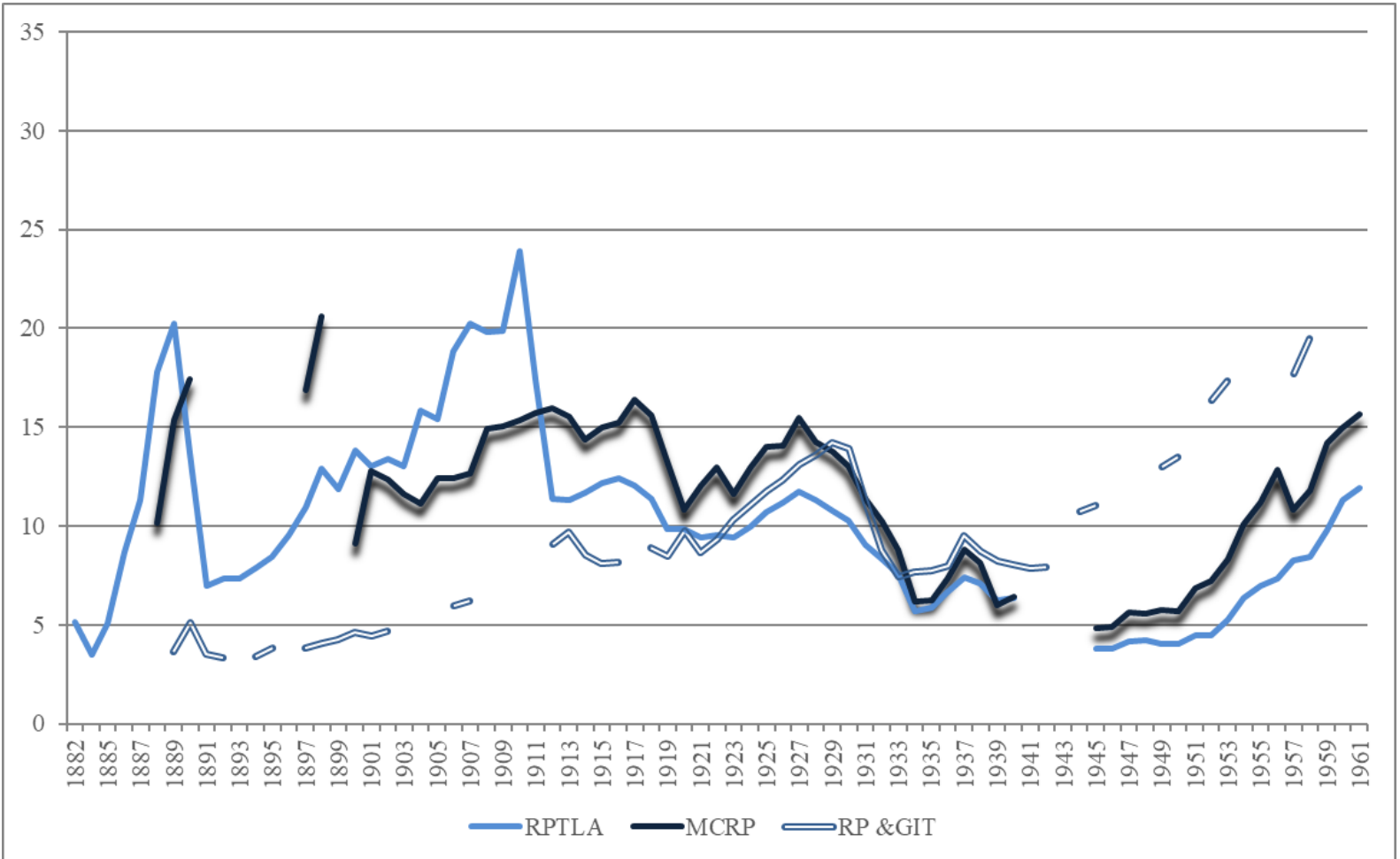

Source: The River Plate Trust, Loan \& Agency, Annual Reports, 1882-1957; Mortgage Co. of River Plate, Annual Reports, 1888-1949; The River Plate \& General Investment Trust, Annual Reports, 18881961

** Net profits/Share Capital *100. We consider net profits before tax. Equity and profits are book values, denominated in pounds sterling.

Investments made by MCRP and RP \& GIT show concentrated portfolios of stocks representing assets in the River Plate until WWI. In the 1920s, those portfolios began to diversify with the addition of government securities and, later, shares from British industrial companies. However, during their second boom, firms again featured highly concentrated portfolios: 87 per cent of their investments focused on British industrial companies' assets. Thus, in expansion cycles, the portfolios grew more concentrated. This strategy indicates that — as noted in a study of British firms in Asia (Jones and Wale 1998) - British groups typically invested in one country and a single industry. 
FigurE 3. Net Profits of The River Plate Trust, Loan \& Agency, Mortgage Company of the River Plate and The River Plate \& General Investment Trust, 1882-1961 (in £)

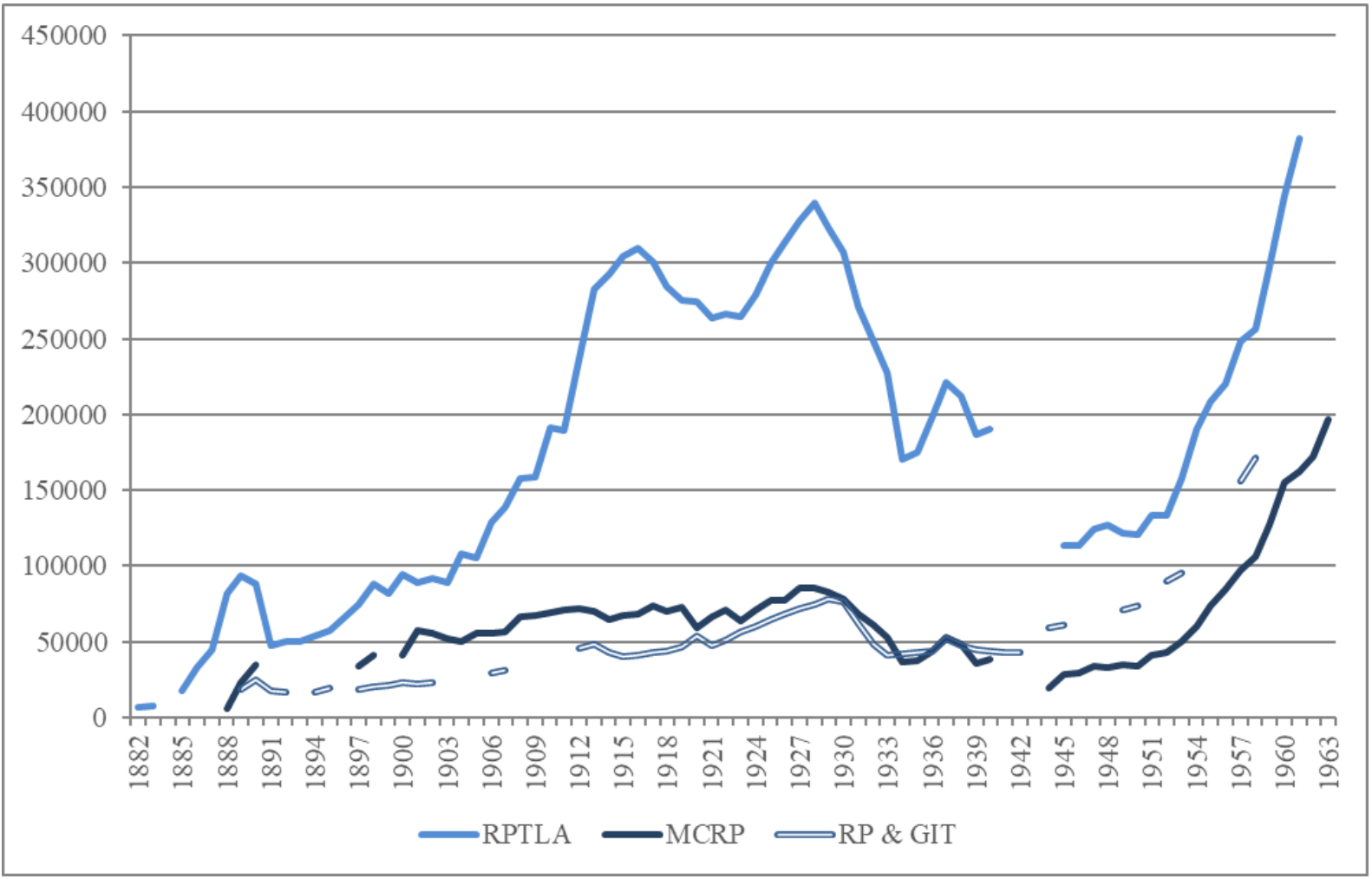

Source: The River Plate Trust, Loan \& Agency, Annual Reports, 1883-1957; Mortgage Co. of River Plate, Annual Reports, 1888-1949; The River Plate \& General Investment Trust, Annual Reports, 18881961.

In general terms, the River Plate Trust's financial and mortgage companies performed better than average: The ROEs of these companies reached the same level as those of Borneo Co., the most profitable British trading company in colonies such as Malaysia. Except during financial crises and world wars, their profitability exceeded 10 per cent, with peaks of about 20 per cent. Both RPTLA and MCRP showed higher profitability rates than the 12 per cent secured by leading British banks in the region, such as The London \& River Plate Bank and he London \& Brazilian Bank. The ROEs of River Plate Trust's firms proved even higher than those of the most successful banks in other regions, such as The Hong Kong \& Shanghai Banking 
Corporation over the entire period. Only in the late 1940s did profit ratios begin to draw closer (Jones 2000, 1999).

The River Plate Trust's case shows that net profits and return rates of British financial and mortgage firms in the River Plate increased remarkably starting in the mid-1890s, peaking in 1910 and from 1925 to 1929. A long-term analysis undermines evidence for the declining trend for rates of return after WWI reported by studies of periods up to 1913 (Davis and Huttenback 1982; Edelstein 1976).

Figures 1-3 show that the Great Depression, followed by currency devaluations, impaired the performance of financial and mortgage firms in the region. The Report of Proceedings at the General Meeting of Shareholders in 1934 expressed concern for the new exchange rate, which had affected gold agreements, and for the profit-remittance restrictions enforced by Argentina's government, which forced companies to reinvest their earnings in the host economy. Investment transfers back to Great Britain over the preceding decade reveal that investment opportunities in businesses in which RPTLA enjoyed competitive advantages had reached their limit in Argentina and Uruguay. The remarkable recovery of profits, profitability, and dividends from financial and mortgage companies during the second post-War period no longer accounted for the performance of assets in the River Plate; it came from Great Britain, where investments had returned (RMTR. The River Plate Trust, Loan \& Agency, Proceedings, March 26, 1934).

The companies of the River Plate Trust showed a moderate-to-low leverage ratio and high reserve-to-equity ratios. That is, these companies were low-risk, highly profitable businesses during 1885 to 1930 , and they experienced a moderate increase in risk and moderate 
profitability during 1932 to 1947 . In all cases, return on investment far exceeded the capital invested during the business cycle

In Latin America, the Gibbs and Balfour groups displayed similar features, with their differences stemming from the dissimilarities between Peru's market and those of Chile, Argentina, and Uruguay. Because of the type of investments required for mining in Peru and the position of Peru's economy, attracting capital proved to be harder for Peru than Chile or Argentina; it drove groups to lean toward portfolio rather than direct investments (Miller 1998). Still, the issues that arose after the 1930s were the same for all groups operating in Latin America.

\section{River Plate Trust's Public Utility Companies in Argentina and Uruguay}

The River Plate Trust Group controlled three public utility companies in the region: Consolidated Water Works Co. of Rosario and Rosario Drainage Co., in Rosario, as well as The Montevideo Waterworks Company, in Montevideo. The MWW was the first company owned by the River Plate Trust group. In 1879, the company took over a concession to build and manage the running water system in Montevideo; it was transferred to Uruguay's state in 1948. The MWW's early success soon drew London shareholders' attention. In just a few years, it had secured satisfactory financial profitability, driving group investments into other utility concessions in the River Plate.

Montevideo's water system concession, as well as subsequent agreements forged by the firm with Uruguay's government, proved very beneficial for the company (Finch 2014). For the first 12 years, the government guaranteed tax waivers, state subsidies for construction works, and exclusive arrangements. Moreover, the rate per cubic meter of water, set in gold-convertible 
pesos, was very high — double the rate established in other cities (Lanciotti and Regalsky 2014). Even when the exclusivity clause expired, the distance separating the city from supply sources demanded costly investments that hindered the arrival of new competitors, as MWW officials pointed out to their shareholders (The Montevideo Waterworks Co., Annual Report, 1890; Proceedings, 1895).

FigURE 4. The Montevideo Waterworks: Return on Equity (ROE) and Return on Assets (ROA), $1880-1947 * * *$

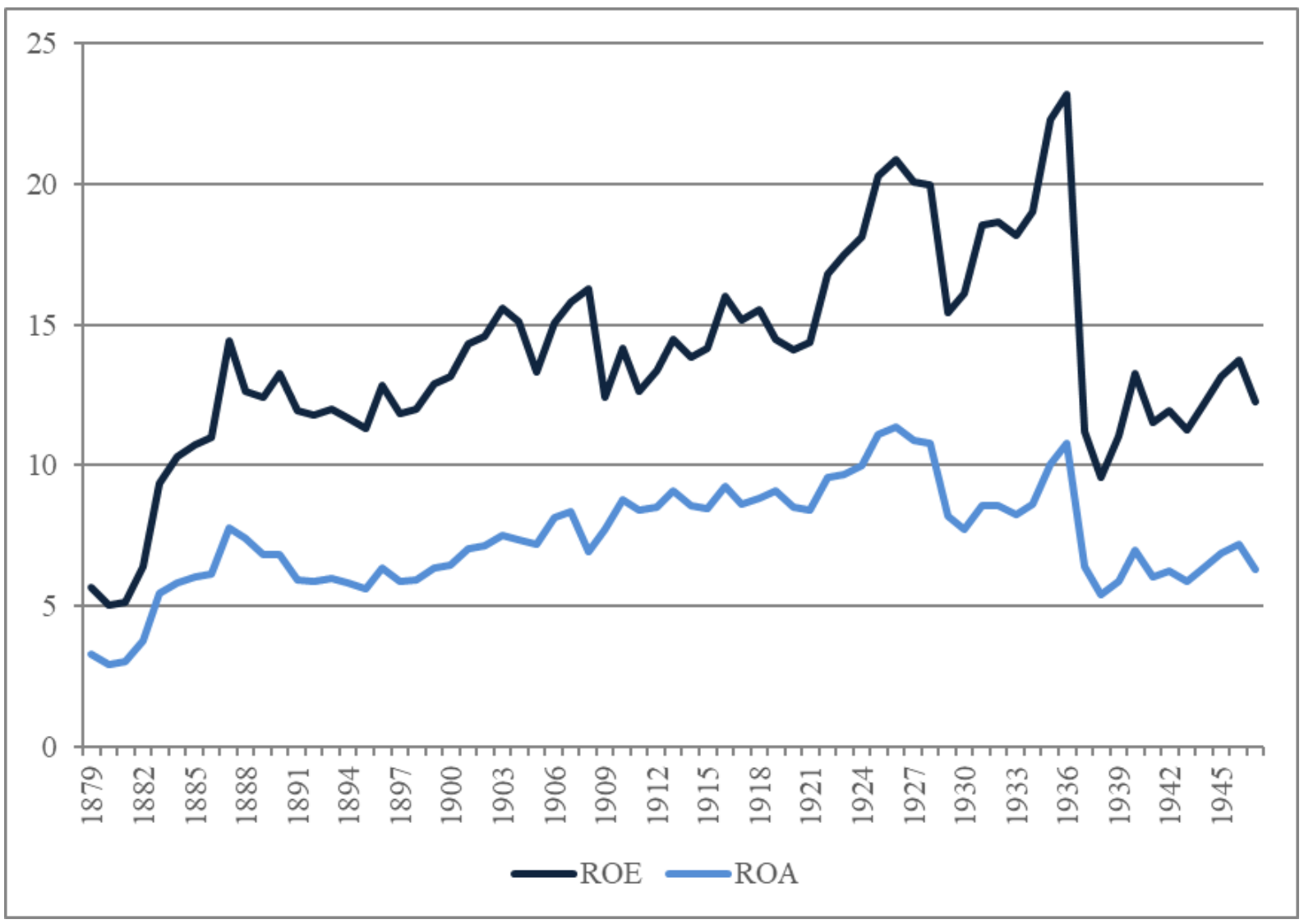

Source: MWW, Annual Reports, 1880-1947

$* * *$ ROE (Return on Equity): Financial Profitability $=$ Net profits/Share Capital $* 100$.

ROA (Return on Assets): Economic Profitability $=$ Net profits/Assets $* 100$.

Those initial advantages, against a backdrop of swift population growth by immigration, brought increasing earnings that stemmed from economies of scale in Montevideo's water 
network, boosting the firm's capitalization. ${ }^{18}$ Company assets continued to rise even after 1930. As a result of high tariffs and entry barriers, MWW became the most highly capitalized and profitable utility owned by the River Plate Trust group (Figures 4 and 5).

Both MWW's financial and economic profitability rates exceeded European firms' average profitability throughout this period. Its ROE rose above 15 per cent from 1927 to 1936 and dropped below 10 per cent only in 1938, as the result of devaluation caused by a new exchangerate scheme. It then rose again until the waterworks system was nationalized. ${ }^{19}$

The economic performance of MWW proved even more compelling: Its return on assets (ROA) was the highest in the group, exceeding 5 per cent throughout its operating period and peaking at 11 per cent in 1925. Even during the 1930s and until the end of its concession, MWW accomplished satisfactory profitability. The firm maintained high earnings when exchange rate losses increased after the crisis in $1930 .^{20}$ These indicators provide an explanation for the increased capital investments in MWW throughout its existence, until it was sold to Uruguay's government in 1947 (Figure 5). In 1950, the Uruguayan state took over the system, after transferring its total assets for an accounting value of $£ 3,320,000$ (RMTR. The Montevideo Waterworks Co., Final Report of Liquidation, 1953).

\footnotetext{
${ }^{18}$ Montevideo's population grew from 215,000 in 1889 to over 655,000 in 1930 . During the 1930 s, the urban population continued to grow to nearly 750,000 (Nahum 2007).

19 A new "managed exchange rate" scheme was enforced on December 4, 1937 to replace the official exchange rate in place since 1931. This new scheme established a spread between foreign currencies bought and sold in the local market, under the supervision of Banco de la República Oriental del Uruguay (Bertino, Bertoni and García Repetto 2004). The exchange rate control scheme had been instituted in Argentina in 1931.
}

${ }^{20}$ MWW's ROE stood at par with the highest ROEs of other European firms (Cassis 1997). 
Figure 5. Assets of The Montevideo Waterworks Co., Consolidated Waterworks of Rosario (Rosario WW) and Rosario Drainage Co., 1879-19476 (in 000’s £)

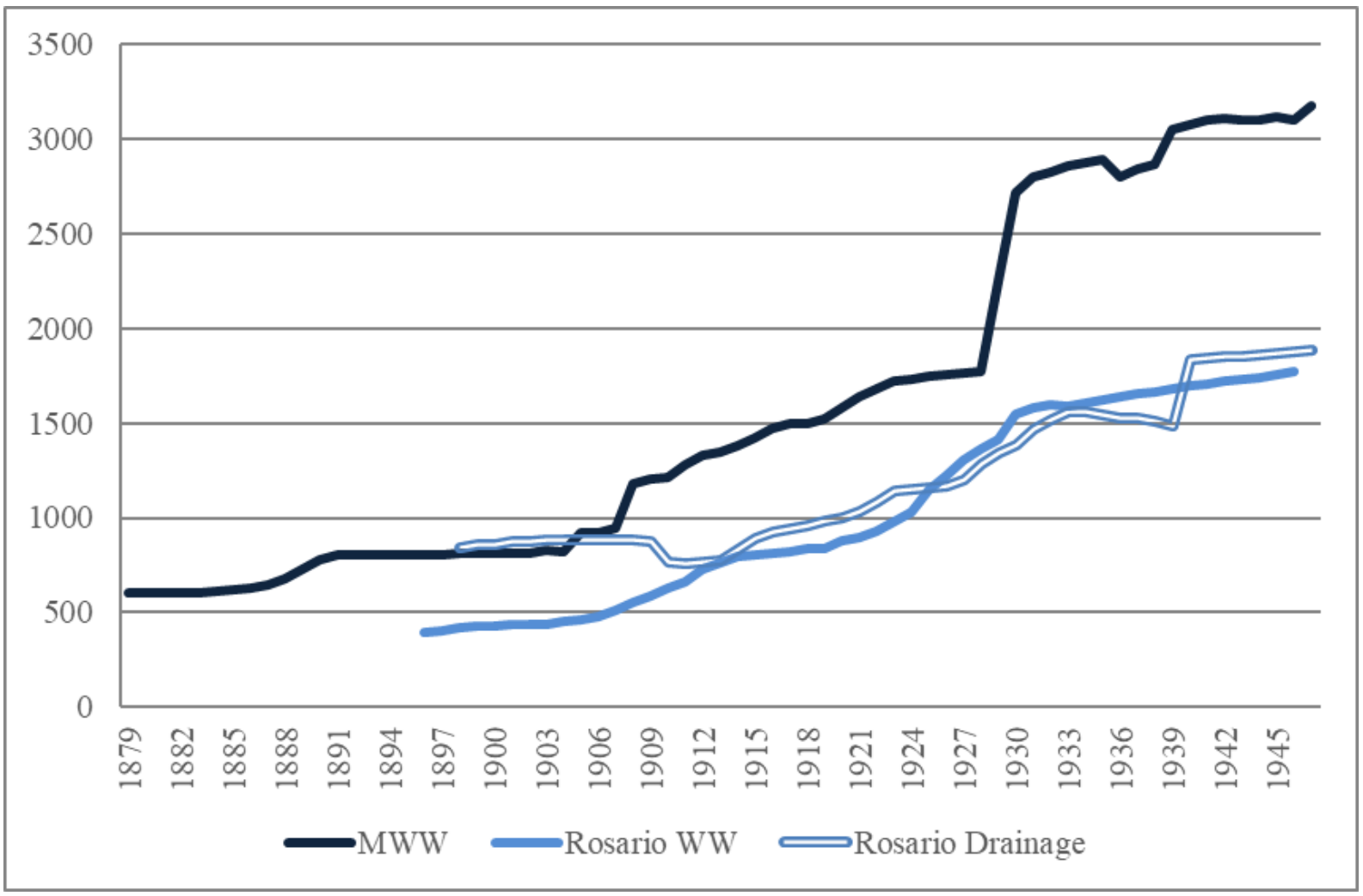

Source: MWW, Annual Reports, 1880-1947, Consolidated Water Works Co. of Rosario, Annual Reports, 1896-1946; Rosario Drainage Co., Annual Reports, 1899-1946.

Although the Consolidated Water Works Company of Rosario did not perform as resoundingly as MWW, its economic and financial profitability proved very satisfactory throughout this period, except during war years. Once the Consolidated Water Works Company of Rosario was reorganized in 1896, its performance proved outstanding. However, the Rosario Drainage Co. was unable to put its network in operation, undergoing several conflicts with the local government. Because the optimal operation of the water works system depended on its integration with the home sewage system, the delay in bringing that system to effective operation, coupled with the breach in a time-is-of-the-essence clause, negatively affected the performance of the water company. 
However, in 1901, continuation of drainage works and a system expansion began to ensure significant profitability. Thus, investments in facilities were resumed, and a new purifying plant was installed. Water consumption doubled from 1905 to 1912, and both companies increased their revenues as a result of rising household connections and property values in a period of economic and population growth. At that time, the board proposed extending the network. As in Montevideo, the companies' operating period coincided with remarkable population growth in the port city of Rosario in Argentina's main export region. ${ }^{21}$

During WWI, recession drove a drop in the number of services. Consolidated Water Works' profits began to fall in 1915 (see Figure 6). Increased fuel costs as a result of imported coal substitution by firewood in 1915 and 1916 also had a negative impact on income.

The Rosario Drainage Co. remained unaffected though, because of its lack of dependence on imported fuel. Despite difficulties in accessing materials to finish the works, particularly imported cement from Great Britain and the United States, the firm's net profits increased during WWI as the result of a more household connections resulting from system expansion.

By 1919, the situation had returned to normal. Wood supply and access to ferric aluminium (used to purify water) were resolved; fuel and input prices were falling. Operating costs diminished and profits increased. The Rosario Drainage Co. took out temporary loans and reinvested earnings. Investing in system expansion proved to be the right decision, because it expanded the benefits of economies of scale. This situation was recognized by the company's

\footnotetext{
${ }^{21}$ Rosario's population grew from 50,914 in 1887 to 468,000 in 1947 , when companies were sold to the government.
} 
chair in 1923, when he reported to shareholders that revenues would grow along with rentals in Rosario.

Figure 6. Consolidated Water Works of Rosario's and The Rosario Drainage Company's Net Profits, 1896-1944

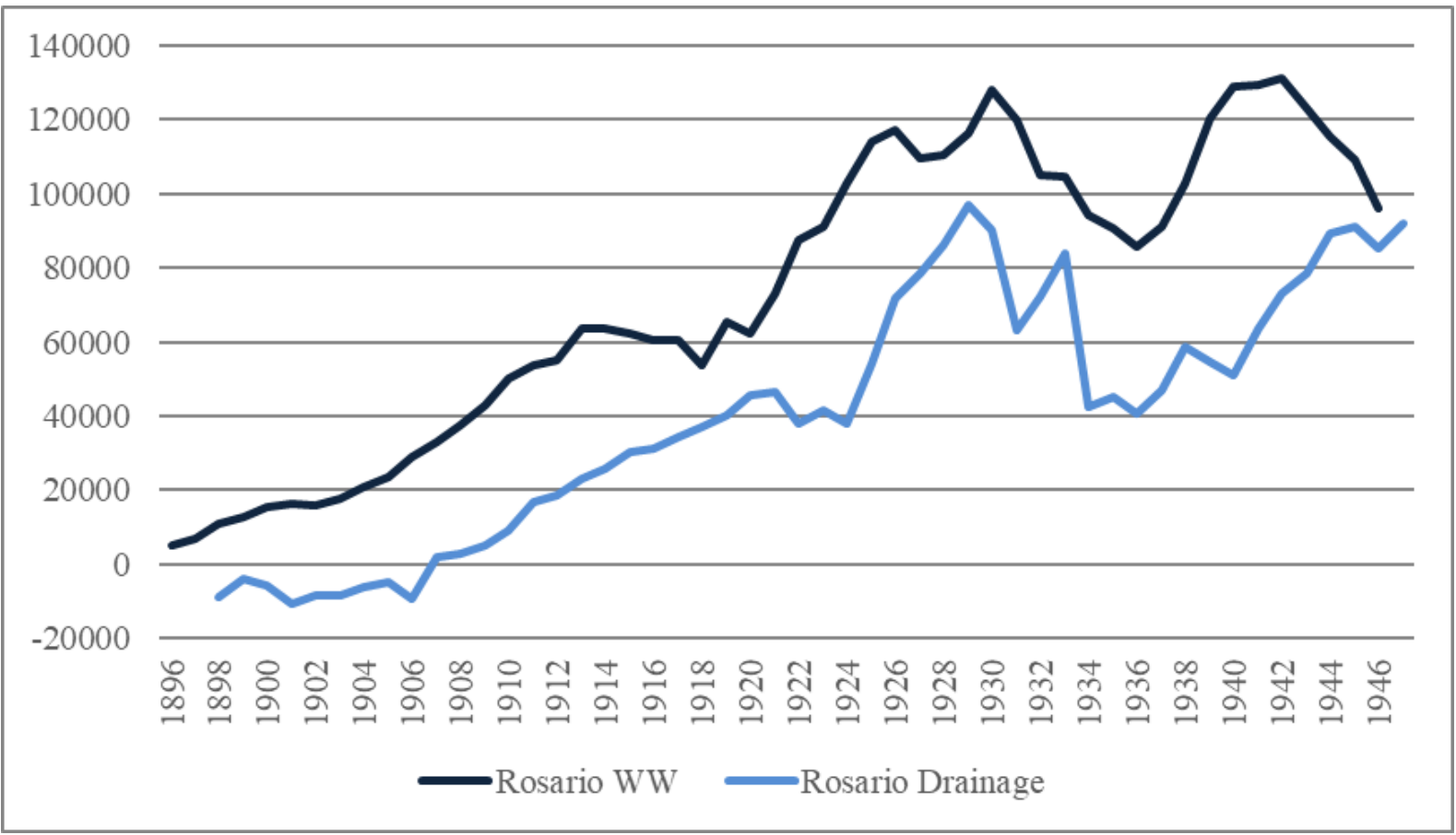

Source: Consolidated Water Works Co. of Rosario, Annual Reports, 1896-1946; Rosario Drainage Co., Annual Reports, 1899-1946

Several shareholders raised objections to raising additional capital; they preferred short-term, higher dividends to investing in company growth and services. Chair James Anderson explained that the investment in "the new areas will yield enough income to pay a satisfactory interest on the capital cost, and also to provide for redemption to the capital" (Consolidate Waterworks Company of Rosario, Annual Reports (1925), 7). He also clarified that issuing debentures would not create a problem for the company, because there were still 30 years left before the concession agreement expired. Anderson's explanation encouraged shareholders to issue new 
shares, but the issue was rejected by the board in favour of issuing debentures, ${ }^{22}$ complemented in 1927 by new equity shares.

In 1931, the crisis struck utilities hard, and additional users did not offset falling rental prices. Argentina's currency devaluation increased exchange rate losses, and restrictions on foreign exchange remittances prevented dividend distribution. Both companies' net incomes dropped. However, even during the most difficult years, earnings did not fall below the mid-1920s level (Figure 6).

Profitability (ROE) fell slightly more, down to pre-war levels (Figure 7). Against this backdrop, companies restricted investments, increased their reserves, reduced dividend distribution, and issued no additional equity. ${ }^{23}$ These decisions implied a shift in the River Plate Trust Group's corporate policy, as a result of a change in the region's business outlook. The RPTLA's managers believed that investment opportunities in operations in which the group enjoyed some advantages had reached their limit in Argentina and Uruguay (Lanciotti 2011).

In contrast with the case of MWW, board members at Rosario's companies heeded the local government's increasing criticism of foreign utilities. Because concession contracts had set fees in gold pesos, the service became more expensive in local currency, leading consumers to default on their payments and the company to cut off services. The local government stepped in on behalf of consumers, enforcing a $20 \%$ discount on fees. As a result, G. Harnett Harrison, director at Consolidated Water Works Co. of Rosario, travelled urgently to Argentina to press

\footnotetext{
${ }^{22}$ Shares involve property rights. If the interests on dividend payments are low, it is more convenient to fund new investments by issuing dividends.

${ }^{23}$ The introduction of the income tax as of January 1934 did not decisively impact on company profits, because it included 5 to 7 per cent of annual profits, about half Britain's income tax.
} 
for the suspension of this executive order. Agustín P. Justo, Argentina's President at the time, intervened, and the fee discount was removed (Compañía Consolidada de Aguas Corrientes 1935).

FigURE 7. Consolidated Water Works of Rosario's and The Rosario Drainage Company's Return on Equity (ROE), 1896-1944

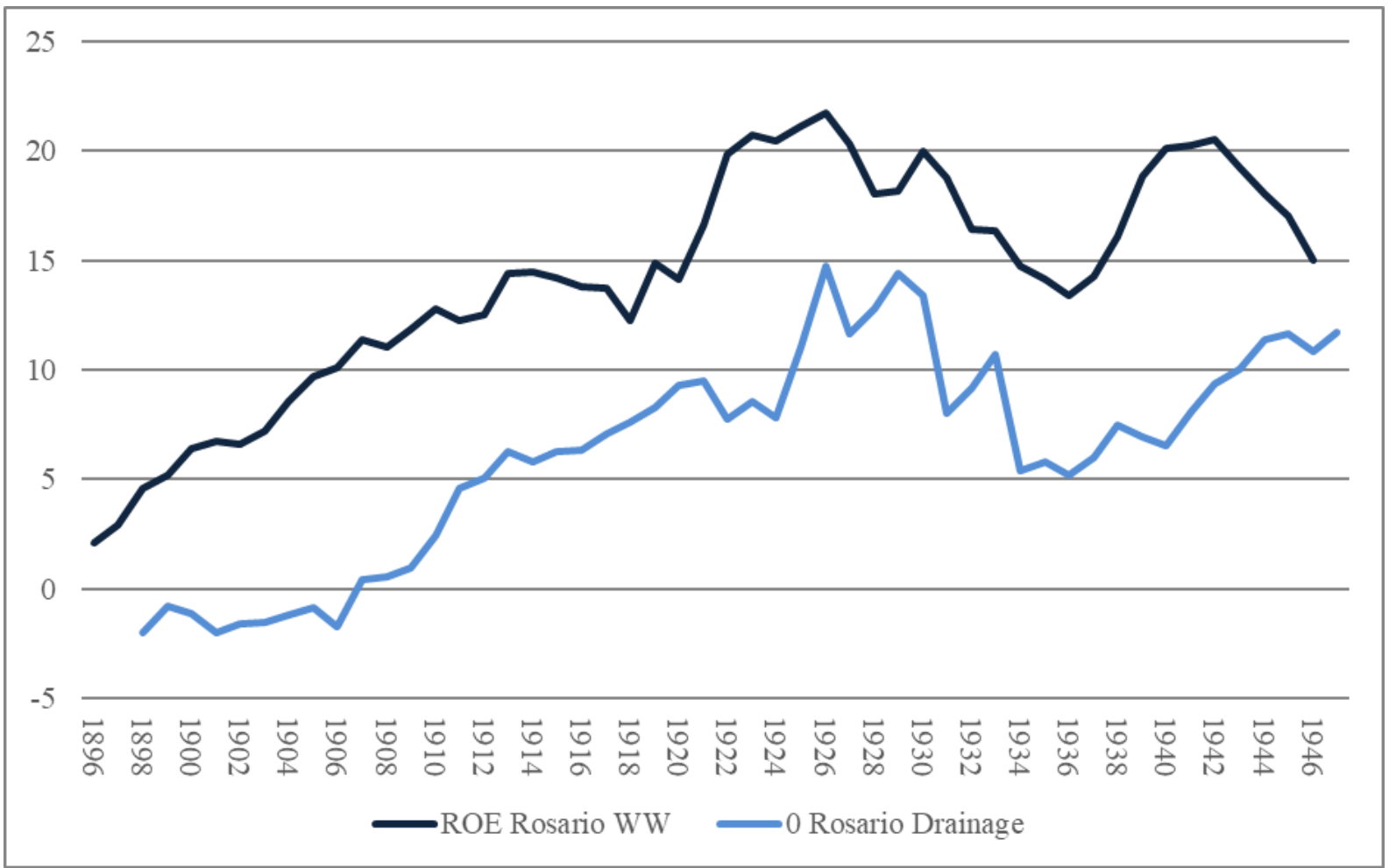

Source: Consolidated Water Works Co. of Rosario, Annual Reports, 1896-1946; Rosario Drainage Co., Annual Reports, 1899-1946.

The Rosario Drainage Company's fixed assets decreased between 1929 and 1938 but then rose from 1939 on, whereas its capital increased very little. Consolidated Water Works' assets and capital remained stagnant between 1929 and 1946 (Figure 5). The system expanded between 1900 and 1930, but service expansion grew at a slower rate after 1930. As the number of users grew faster than the network, the system worked more intensely. In turn, in 1935, Consolidated Water Works Co. began to install home water meters, which helped reduce overall water consumption while increasing the number of users. This innovation led to a steady annual water 
consumption rate between 1936 and 1940, despite a larger number of connections, which boosted the firm's profits after 1936.

In 1941, Consolidated Water Works reorganized common and preferred shares in a single stock to divest itself of its business. Although exchange-rate losses peaked in 1942, the firm reported record profits that exceeded the 1930 mark. Operating costs soared in 1943 as a result of fuel shortages and municipal restrictions on rate increases, compounded by wage increases and the introduction of social security and pensions in 1945. The use of fuel oil enabled a cost-based economy that was insufficient to offset wage increases with frozen rates and a 100 per cent income tax hike in 1946. At the same time, to meet its obligations, the company started selling some of its portfolio investments, which was a sound decision in a context of increasing prices and decreasing profits.

Urban utilities' economic growth after the crisis in 1930 differs from the path followed by tramway and railway companies, the profitability of which peaked at the beginning of their operations but started to decline in the 1920s and 1930s, respectively. The downfall of tramway companies began during WWI, when operating costs soared as a result of coal shortages. In the 1920s, their profits did not return to pre-War levels, and the crisis in 1930 worsened their financial distress just as tensions between the companies and local society heightened, featuring successive strikes and users' persistent complaints about poor service (García Heras 1994, Rosenthal 1995).

British railways' incomes instead rose in 1923, driven by increased fees and traffic rekindling. After that point, most companies, with the exception of The Central Argentine Railway Co., invested in railway expansion and electrification. In 1930 however, gross revenues fell as a 
result of the economic slowdown; currency depreciation, the introduction of exchange rate controls, and restrictions on foreign exchange remittances also curbed British firms' profitability and increased their indebtedness. These restrictions affected other foreign firms, but private railroad companies had to face rising competition from automotive transport in the 1930s (Salerno 2007; Lewis 2007).

British companies' strategies to navigate the crisis failed to revert this trend. Their demands that the Argentine government release foreign exchange and pass a law to regulate automotive transport did not succeed. By 1933, Argentine politicians and British railways directors and financial officials proposed the idea of nationalizing railroads (López 2016). Furthermore, strained trade relations between Great Britain and Argentina, as well as the accumulation of negative trade balances in pounds during WWII strengthened the thrust to nationalize railroad companies. Major British companies' board members wanted to sell off their companies to the government - a stance supported by the British government, which had decided to include the issue in its negotiations with Argentina with regard to blocked balances in pounds. After several negotiation rounds, in February 1947 Argentina agreed to purchase railway and non-railway assets in the country belonging to British companies for $£ 150$ million. Assets effectively were turned over a year later (López 2016). ${ }^{24}$

Unlike the situation of British railway companies, the financial profitability of water companies in Rosario and Montevideo largely exceeded other European firms' profitability levels in the 1930s and 1940s. This difference may be attributed to the conditions granted to utilities, the

\footnotetext{
${ }^{24}$ On the stance adopted by major railway companies' board members in London and the diplomatic conflicts during the war, see Kelly (1952).
} 
contracts of which guaranteed exclusive service supply, with fees set at gold-convertible prices at a time of significant economic and population growth in Montevideo and Rosario. Utility companies that had invested heavily in fixed assets benefited from economies of scale as a result of service expansion. Thus, MWW and The Rosario Drainage Co. continued to invest even after 1930.

Due to the growing political risk of investments in Europe, investments in the Southern Cone proved not only profitable but safe. However, after 70 years, Great Britain's investment and indebtedness cycle in the region was coming to an end. Despite the satisfactory performance of utility companies controlled by the River Plate Trust, group officials anticipated the end of this business cycle in the region. After a long booming phase, they expected a decline, just as similar businesses in other latitudes had undergone. In 1949, RPTLA's president, Walter Woodbine Parish, referred to sanitation companies' nationalizations in Argentina and Uruguay in the following terms:

These nationalisation programmes have in a good many instances deprived us of first class investments which were yielding us well, and it is difficult as things are today to replace them maintaining security and income. I would mention as a particular example of nationalisation, the Montevideo waterworks, with which we have been closely associated for many years, and in which we have a substantial holding. We have been receiving an income at the rate of over 10 per cent per annum on a book cost of 36000 pounds (RMTR. The River Plate Trust, Loan and Agency. Notes for Chairman Speech at Annual General Meeting to be held on Monday, February $28^{\text {th }}, 1949$, Minute book ${ }^{\circ} 6$ 1939-1949).

Parish believed the sale of sanitation companies to Argentina's and Uruguay's governments marked the end of Great Britain's investment cycle in Latin America:

Our investments in South America have decreased from 16.89 per cent in 1947 to 10.07 per cent in the year under review, and it seems probable that our stake in the Latin 
American countries will be reduced to a very small figure in the near future. I mention this as in looking back I find it was as recently as 1944 the percentage was over 31 (RMTR. The River Plate Trust, Loan and Agency. Notes for Chairman Speech, February $\left.28^{\text {th }}, 1949\right)$.

\section{Final Remarks}

We start by noting the long lifecycle of River Plate Trust's British firms. These companies operated in the country for 70 years. Their long track records challenge the thesis about the end of British FDI's cycle after WWI. Instead, the trajectory of the River Plate Trust confirms that Great Britain's investment cycle ended at the same time that Anglo-Argentine commerce and trade declined in the mid-1940s.

The companies affiliated with River Plate Trust continued to operate and produce consistent profits throughout the period. Both profitability ratios and dividend distributions showed steady, successful performances in all cases; however, the distinction between contributions from mortgage and financial firms and from public utilities companies should be noted.

Mortgage and financial firms, the operations of which would largely amount to British portfolio investments, showed a gradual investment refocus from Argentina and Uruguay to their home country, starting in WWI. Investments in the River Plate region, which accounted for 83 per cent of RPTLA's overall investments, dropped to 47 per cent by 1923, 27 per cent by 1932, and 11 per cent by 1946 . Similarly, RP \& GIT reduced its assets in the region to 31 per cent of its total by 1938 and to 17 per cent by 1947 .

These reductions reflected the displacement of mortgages as these firms' core businesses. By the end of WWI, investments by RPTLA and MCRP were refocused to financial assets in other 
regions, as shown by the increased share of "Other Investments" in both companies' assets, which drew away from mortgage loans since 1918.

The MCRP was the first company to reorganize itself to operate in another region; by 1949, only 6 per cent of its investments were located in the River Plate. In contrast, because RP \& GIT's investment portfolio consisted largely of securities from firms operating in this region, it maintained its investments until the 1940s, when major British firms were sold to Argentina's government.

These firms' gradual withdrawal-particularly from mortgage operations — was driven by managers' assessments of the outlook for ending a business cycle that initially had been driven by the speedy growth of a 'new economy' in the periphery. A maturing Argentine economy and the emergence of loan mechanisms other than mortgage market offerings curtailed the growth of these operations. The withdrawal was not abrupt or forced; rather, it pursued an investment strategy that already had been proven in other latitudes by the group's early managers.

The mortgage business had not ceased to be profitable, as James Anderson, RPTLA's chair, correctly observed. The changing conditions that drove initial investments were the key reason for investment portfolio reorientation; the earnings produced by the group's mortgage and financial firms rose during the 1920s, and their ROEs also remained high. Thus, the decision to refocus investments on financial assets in other regions did not come as a result of decreasing profitability or an unfavourable policy for British companies. Profitability did not fall until the 1930s, and the fall was caused by exchange rate losses resulting from Argentina's departure from the gold system and the peso devaluation. 
In the 1940s, the rising trend returned. Nonetheless, we cannot associate earnings of the mortgage and financial firms of the River Plate Trust group during this decade with Argentine businesses: Only 11 per cent of their investments were located in the River Plate by 1946 . The shift in the earnings trend of River Plate Trust's mortgage and financial firms in the 1940s marked a new expansion cycle associated with transactions involving securities in Britain's stock market.

In contrast, like other British FDI, the utility companies controlled by the group maintained their assets in Argentina. In the 1920s, MWW, Consolidated Water Works, and Rosario Drainage Co. continued to invest in the host economy until the facilities were sold to the governments of Argentina and Uruguay in 1947; MWW's capital raising and fixed assets continued to grow in the 1930s to expand Montevideo's water system and leverage economies of scale. This strategy proved successful for the company, driving higher earnings and dividends in the 1930s.

In Rosario's sanitation companies, capital raising was interrupted by the crisis in 1930, but fixed assets increased slightly in the 1930s. Rosario Water Work's financial and economic profitability remained high throughout this period. As for the Rosario Drainage Co., construction deficiencies and clashes with local authorities caused a significant delay in system development, which hindered acceptable profitability until the 1920s. However, the company subsequently produced high earnings (though not as high as Rosario Water Works) and adequate profitability. In both cases, lower profitability in the first half of the 1930s compared with the previous decade's ROE and ROA resulted from exchange rate losses. Even so, Rosario Water Works secured very high ROE and ROA levels, and the Rosario Drainage Co. also quickly recovered lost ground. 
The contrast between these firms' performances and those of tramway and railroad companies, especially after 1930, highlights that, though the former continued to operate with no competition and with gold-convertible fees in a setting characterized by growing urban service demand, the latter faced decreasing demand as they competed with road transport. Furthermore, group companies' profitability proved higher than the average profitability of European firms during this period and resembled leading British banks' profitability in other regions.

When we analyse how business operations evolved across the group's companies, the complementarity of both investment types becomes clear. Profitability curves rose at different business cycle phases, with financial and mortgage firms becoming more profitable first and utility companies taking the lead after the 1930 crisis. The diversification of investments in a single region helps explain the long life cycle of River Plate Trust's firms. The management and organizational capabilities of the group guaranteed sound investment performance and a steady distribution of company dividends.

Our analysis also clearly shows that the profit return phase lasted far longer than the capital inflow phase and that the capital initially invested in all companies was recovered before WWI. Moreover, it shows that capital returns far exceeded capital inflows, confirming that the British investment cycle spanned an investment and indebtedness period that lasted 70 years in this region. Profits and survival confirm the corporate success of River Plate Trust in Argentina and Uruguay.

Our long-term analysis establishes that the decline of British investments in the region was not the result of managerial shortcomings in groups and companies; quite the contrary, for a long time, group officials successfully maintained competitive advantages they acquired as a result 
of their specific knowledge, reputation, and long-term relationships between home and host economies. Neither was this decline caused by nationalist policies or foreign capital-averse measures; sanitation companies were sold to the Argentine and Uruguayan governments in mutually agreed-upon transactions based on company assets' accounting value. Furthermore, according to group officials themselves, the nationalizations that deprived them of the high returns produced by their investments marked the end of a business cycle in this region.

We make two final, additional points. First, the foreign investment cycle does not come to an end when multinational companies refocus their investments; it ends when companies leave the region. From the standpoint of host economies, when the initial capital inflow phase is followed by an earning outflow phase, outflow volumes substantially exceed investments in even the least successful cases. Second, to determine British firms' life cycles during the first global economy, it is necessary to look at the track records of investment groups that manage business strategies. Thus, our study demonstrates the different stages of the investment and indebtedness cycle led by British firms in the River Plate area.

\section{References}

Barbero, María Ines. 2015. "Business Groups in nineteenth and twentieth century Argentina." In The Impact of Globalization on Argentina and Chile: Business Enterprises and Entrepreneurship, edited by Geoffrey Jones and Andrea Lluch, 6-44. London: Edwar Elgar Publishing.

Barrán José y Benjamín Nahum. 1968. Historia Rural del Uruguay moderno. Vol. V, La prosperidad frágil, 1905-1914. Montevideo: Ediciones de la Banda Oriental.

Bertino, Magdalena, Reto Bertoni and Ulises García Repetto. 2004. "Impuesto Cambiario y subsidios, Uruguay 1937-1959." Serie Documentos de Trabajo DT 6/06. Montevideo: Instituto de Economía-FCEA.

Cassis, Youssef. 1985. "The Banking Community of London, 1890-1914: A Survey.” The Journal of Imperial and Commonwealth History 13(3): 109-126. doi: 10.1080/03086538508582695. 
Cassis, Youssef. 1997. Big Business. The European Experience in the Twentieth Century. Oxford: Oxford University Press.

Casson, Mark. 1994. "Institutional Diversity in Overseas Enterprise: Explaining the Free-Standing Company." Business History 36(4): 95-108. doi: 10.1080/00076799400000126.

Coopey, Richard, and Peter Lyth. 2009. Business in Britain in the Twentieth Century. Oxford-New

York: Oxford University Press.

Corley, Thomas Anthony Buchanan. 1994."Britain's Overseas Investments in 1914 Revisited." Business History 36(1): 71-88. 10.1080/00076799400000004.

Davis, Lance, and Robert Huttenback. 1982. "The Political Economy of British Imperialism: Measures of Benefits and Support." The Journal of Economic History 42(1): 119-130. doi: 10.1017/S0022050700026966.

Dunning, John. 1970. Studies in International Investment. London: Allen \& Unwin.

Edelstein, Michael. 1976. "Realized rates of return on U.K. Home and overseas portfolio investment in the age of high imperialism." Explorations in Economic History 13(3): 283-329. doi: $\underline{10.1016 / 0014-4983(76) 90010-3 .}$.

Finch, Henry. 2014. La economía política del Uruguay contemporáneo, 1870-2000. Montevideo: Ediciones de la Banda Oriental.

García Heras, Raúl. 1994. Transporte, negocios y política. La Compañía Anglo Argentina de Tranvías. 1876-1981. Buenos Aires: Sudamericana.

Greenhill, Robert. 1995. "Investment Group, Free-Standing Company or Multinational? Brazilian Warrant, 1909-52." Business History 37(1): 86-111. doi: 10.1080/00076799500000005.

Goetzmann, William, and Andrey Ukhov. 2005. "British Investment Overseas 1870-1913: A Modern Portfolio Theory Approach." Working Paper 11266, Working Paper Series; Cambridge. Available at http://www.nber.org/papers/w11266. 812-855.

Hannah, Leslie. 2009. "Strategic Games, Scale, and Efficiency, or Chandler goes to Hollywood." In Business in Britain in the Twentieth Century, edited by Richard Coopey and Peter Lyth, 33-47. Oxford-New York: Oxford University Press.

Jones, Charles. 1980. "Great Capitalists and the Direction of British Overseas Investment in the Late Nineteenth Century: The Case of Argentina." Business History 22(2): 151-169. doi: 10.1080/00076798000000024.

Jones, Charles. 1997. "Institutional Forms of British Foreign Direct Investment in South America." Business History 29(2): 21-41. doi: 10.1080/00076799700000049.

Jones, Charles. 2004. “Morris, John (1823- 1905).'In The Oxford Dictionary of National Biography, edited by Lawrence Goldman, Oxford: Oxford University Press,. doi: 10.1093/ref:odnb/48070. 
Jones, Charles. 2018. Capitales británicos, sector financiero y gobierno en la Argentina, 1862-1914. Buenos Aires: EDUNTREF.

Jones, Charles; Linda Jones and Robert Greenhill. 1977. "Public Utility Companies." In Business Imperialism 1840-1930, edited by Desmond Christopher St. Martin Platt, 77-118. Oxford: Oxford Clarendon Press.

Jones, Geoffrey, and Judith Wale. 1998. "Merchants as Business Groups: British Trading Companies in Asia before 1945." The Business History Review 72(3): 367-408. doi: 10.2307/3116215.

Jones, Geoffrey. 1999. British Multinational Banking, 1830-1990. Oxford: Clarendon Press.

Jones, Geoffrey. 2000. Merchants to Multinationals. British Trading Companies in the Nineteenth and Twentieth Centuries. Oxford-New York: Oxford University Press.

Kapoor, M.C. and Rajan Saxena. 1979. "Taming the Multinationals in India." Journal of World Trade 13(2): $170-178$

Kelly, David. 1952. The Ruling Few or The Human Background to Diplomacy. London: Hollis \& Carter. Lanciotti, Norma. 2011. "Inversión británica y redes empresariales: La estructura organizativa y las estrategias de gestión del grupo River Plate Trust, Loan \& Agency en Argentina, 1881-1962.” Anuario CEEED 3: 85-126.

Lanciotti, Norma. 2015. "From a Guaranteeing State to an Entrepreneurial State: The Relationship between Argentina's State and Urban Utility Companies, 1880-1955." In The Impact of Globalization on Argentina and Chile: Business Enterprises and Entrepreneurship, edited by Geoffrey Jones and Andrea Lluch, 199-205. London: Edwar Elgar Publishing.

Lanciotti, Norma, and Andrea Lluch. 2010. "Foreign Direct Investment in Argentina: Timing of Entry and Business Activities of Foreign Companies (1860-1950)." Entreprises et Histoire 54(1): 37 66.

Lanciotti, Norma and Andrés Regalsky. 2014. "Los sistemas de agua potable en Argentina: Gestión Pública y gestión privada en dos grandes ciudades, Buenos Aires y Rosario, 1880-1950.” Transportes, Servicios y Telecomunicaciones (TST) 26: 162-197. Available at: http://www.tstrevista.com/tstpdf/tst_26/articulo26_07.pdf.

Lanciotti, Norma, and Andrea Lluch. 2015. "Investing in growing markets: opportunities and challenges for multinationals in Argentina, 1900-1960." Management \& Organizational History 10(2): 119135. doi: $10.1080 / 17449359.2015 .1029949$.

Lewis, Colin. 2007. "Crisis, Tecnología y eficiencia. Los ferrocarriles de capital británico durante los años de transición. 1912-1933". In Nueva historia del ferrocarril en la Argentina, edited by Mario López and Jorge Waddell, 485-518. Buenos Aires: Lumiere.

Lewis, Colin. 1987. "Immigrant Entrepreneurs, Manufacturing and Industrial Policy in the Argentine, 
1922-1928." The Journal of Imperial and Commonwealth History 16(1): 77-108. doi: 10.1080/03086538708582750.

López, Mario Justo. 2016. "Ganancias y pérdidas de los inversores británicos en la venta de los ferrocarriles al Estado argentino en 1947-1948.” América Latina en la Historia Económica 23(2): 122-166. doi: 10.18232/alhe.v23i2.711.

Lluch, Andrea, and Norma Lanciotti. 2012. "Las empresas europeas en Argentina: condicionantes, destinos de inversión y cambios organizativos entre la Primera y la Segunda Guerra Mundial.” Desarrollo Económico 52(205): 119-146.

Marichal, Carlos. 1984. "Los banqueros europeos y los empréstitos argentinos: rivalidad y colaboracion: 1880-1890." Revista de Historia Económica - Journal of Iberian and Latin American Economic History 2(1): 49-54. doi: 10.1017/S0212610900012891.

Miller, Rory. 1998. "British Free-Standing Companies on the West Coast of South America." In The Free-Standing Company in the World Economy, 1830-1996, edited by Mira Wilkins and Harm Schröter, 218-252. Oxford: Oxford University Press.

Miller, Rory. 2013. "Financing British manufacturing multinationals in Latin America, 1930-65." Business History 55(5): 818-839. doi: 10.1080/00076791.2013.800971.

Nahum, Benjamín. 2007. Estadísticas Históricas del Uruguay, 1900-1950, Tomo I. Montevideo: Universidad de la República, Departamento de Publicaciones.

Platt, Desmond Christopher St. Martin. 1977. "Introduction.“"In Business Imperialism 1840 - 1930 An Inquiry Based on British Experience in Latin America, edited by Desmond Christopher St. Martin Platt, 1-14. Oxford: Oxford Clarendon Press.

Platt, Desmond Christopher St. Martin. 1985. "Canada and Argentina: The first preference of the British investor, 1904-14." The Journal of Imperial and Commonwealth History 13(3): 37-41. doi: $10.1080 / 03086538508582693$.

Rippy, J. Fred. 1948. "British Investments in Latin America, 1939." The Journal of Political Economy 56(1): 63-68. doi: 10.1086/256638.

Rippy, J. Fred. 1953. "Background for Point Four: Samples of Profitable British Investments in the Under-Developed Countries“. The Journal of Business of the University of Chicago 26 (2): 110124.

Rippy, J. Fred. 1959. British Investments in Latin America, 1822-1949: A Case Study in the Operations of Private Enterprise in Retarded Regions. Minneapolis: University of Minnesota Press.

Rosenthal, Anton. 1995."The Arrival of the Electric Streetcar and the Conflict over Progress in Early Twentieth-Century Montevideo.” Journal of Latin American Studies 27(2): 319-341. doi: $10.1017 / \mathrm{S} 0022216 \mathrm{X} 00010774$. 
Salerno, Elena. 2007. "La evolución y los problemas de los ferrocarriles del estado en la primera mitad del siglo XX." In Nueva Historia del ferrocarril en la Argentina, edited by Mario López and Jorge Waddell, 395-437. Buenos Aires: Lumiere, .

Slinn, Judy. 1997. Ashurst, Morris Crisp: A radical firm. Cambridge: Granta Editions.

Stone, Irving. 1968. "British Long-Term Investment in Latin America, 1865-1913." The Business History Review 42(3): 311-339.

Stone, Irving. 1977. "British Direct and Portfolio Investment in Latin America Before 1914." The Journal of Economic History 37(3): 690-722. doi: 10.1017/S0022050700095449.

UN-CEPAL-United Nations -Comisión Económica para América Latina. 1959. El Desarrollo Económico de la Argentina.. Mexico: CEPAL.

Wilkins, Mira. 1988. “The Free-Standing Company, 1870-1914: An Important Type of British Foreign Direct Investment." Economic History Review, 41(2): 259-282.

Wilkins, Mira. 2004. The History of Foreign Investment in the United States, 1914-1945. Cambridge MA: Harvard University Press.

\section{Sources}

Compañía Consolidada de Aguas Corrientes de Rosario. 1935. Conflicto por rebaja de tarifas entre la Municipalidad y la Compañía de Aguas Corrientes de Rosario. Rosario.

Consolidated Waterworks Company of Rosario. 1896-1946. Annual Reports. London.

Directory of Directors. 1880-1964. London: Guidhall Library.

Mortgage Company of the River Plate. 188-1949. Annual Reports.

Mortgage Company of the River Plate. January, 1892. Report of Proceedings at the Fifth Ordinary General Meeting of Shareholders.

River and Mercantile Trust Records (RMTR). June 1888. Agreement between the Mortgage Company of the River Plate and the River Plate Trust, Loan and Agency.

RMTR. Mortgage Company of the River Plate, Memorandum and Articles of Association.

RMTR. June 1884. Agreement between the Mortgage Company of the River Plate and the River Plate Trust, Loan and Agency.

RMTR. The Moorside Trust, Memorandum of Association of the Moorside Trust.

RMTR. April 14, 1888. Agreement between The River Plate and General Investment Trust Company Limited and the River Plate Trust, Loan and Agency.

RMTR. 1958. The River Plate Trust, Loan \& Agency, Legal Documents. Reorganization.

RMTR. Registered July $30^{\text {th }}$, 1881. The River Plate, Trust, Loan \& Agency, "Memorandum of 
association of the River Plate Trust Loan \& Agency Company Limited.”

RMTR. The River Plate \& General Investment Trust, Minutes Book.

RMTR. 1953. The Montevideo WaterWorks Co. Final Report of Liquidation.

RMTR. 1939-1949. The River Plate, Trust, Loan \& Agency, Notes for chairman speech at annual general meeting to be held on Monday $28^{\text {th }}$, February 1949. Minute book ${ }^{\circ} 6$.

Rosario Drainage Co. 1899-1946. Annual Reports.

The Montevideo Waterworks Company. 1880-1947. Annual Reports..

The Montevideo Waterworks Company. 1890-1925. Report of Proceedings.

The Moorside Trust. 1961. Annual Report.

The River Plate \& General Investment Trust Co. 1888-1961. Annual Reports.

The River Plate \& General Investment Trust. February 1892. Minutes of proceedings at the Fifth Ordinary General Meeting of shareholders. London.

The River Plate \& General Investment Trust Co. February $24^{\text {th }}$, 1947. Minute ordinary general meeting. The River Plate Trust, Loan \& Agency. 1883-1957. Annual Reports.

The River Plate, Trust, Loan \& Agency. March 1918. Report of Proceedings at the thirty-seventh ordinary General Meeting of shareholders.

The River Plate, Trust, Loan \& Agency. 1889. Report of Proceedings at the ordinary eighth Meeting of shareholders.

The River Plate Trust, Loan \& Agency. March $26^{\text {th }}$, 1934. Report of Proceedings at the Fifty-Third Ordinary General Meeting.

This is an Open Access article distributed under the terms of the Creative Commons Attribution-Non-Commercial-No Derivatives License (http://creativecommons.org/licenses/by-nc-nd/4.0/), which permits non-comercial re-use and distribution, provided the original work is properly cited, and is not altered or transformed in any way. 